This ring retains the battery, when the head of the instrument is removed from the handle for insertion into the instrument case provided, and is a useful feature of the ophthalmoscope. Unfortunately the $1 \frac{1}{2}$ volt unit cells are so manufactured that the zinc casing, which is the negative pole, is exposed at the upper end of the cardboard insulating envelope, and can make contact with the retaining ring of the battery handle.

This causes a short circuit of the lower cell in the battery handle, and only happens when the handle is detached from the head of the instrument.

The remedy is either to depress the battery a little in its cardboard container and roll the edge of the cardboard over the upper rim of the zinc casing of the cell, or to glue a thin ring of cardboard as an insulator under the metal ring in the ophthalmoscope handle.

The correct battery for the ophthalmoscope, the Ever Ready 1829, is a two cell, 3 volt battery, enclosed in a single cardboard envelope the ends of which are rolled over, and so prevent the short circuit described when using two single cells.

$$
\text { Yours faithfully, }
$$

7, Albany Avenue,

$$
\text { P. T. LEES. }
$$

Black POOL.

\title{
OBITUARY
}

\section{IAN STEWART MCGREGOR}

Ophthalmology could ill aftord the death of Dr. Ian Stewart McGregor on January 23 at the age of 43 years, when already he had shown great capacity as clinician, surgeon, teacher and original investigator. $\mathrm{He}$ graduated M.B. CH.B. at the University of Glasgow in 1927 and thereafter filled various resident appointments. His attainments were all the more remarkable in that his interests in ophthalmology began only nine years ago, previous to which he was in general practice on the Island of Bute. This experience in general medicine, however, so broadened his outlook and sharpened his judgment that he learned quickly and fastidiously from his colleagues and within a brief period was appointed Clinical Assistant at the Glasgow Eye Infirmary and Assistant Ophthalmic Surgeon to the Ophthalmic Institution of the Glasgow Royal Infirmary and obtained the Diploma of Ophthalmic Medicine and Surgery granted by the Royal Colleges in England. At the outbreak of war he was mobilised as a squadron leader in the R.A.F.V.R. where he served for two years. His release was requested in 1941 to fill a vacancy as Visiting Surgeon to the Ophthalmic Institution. He also acted 


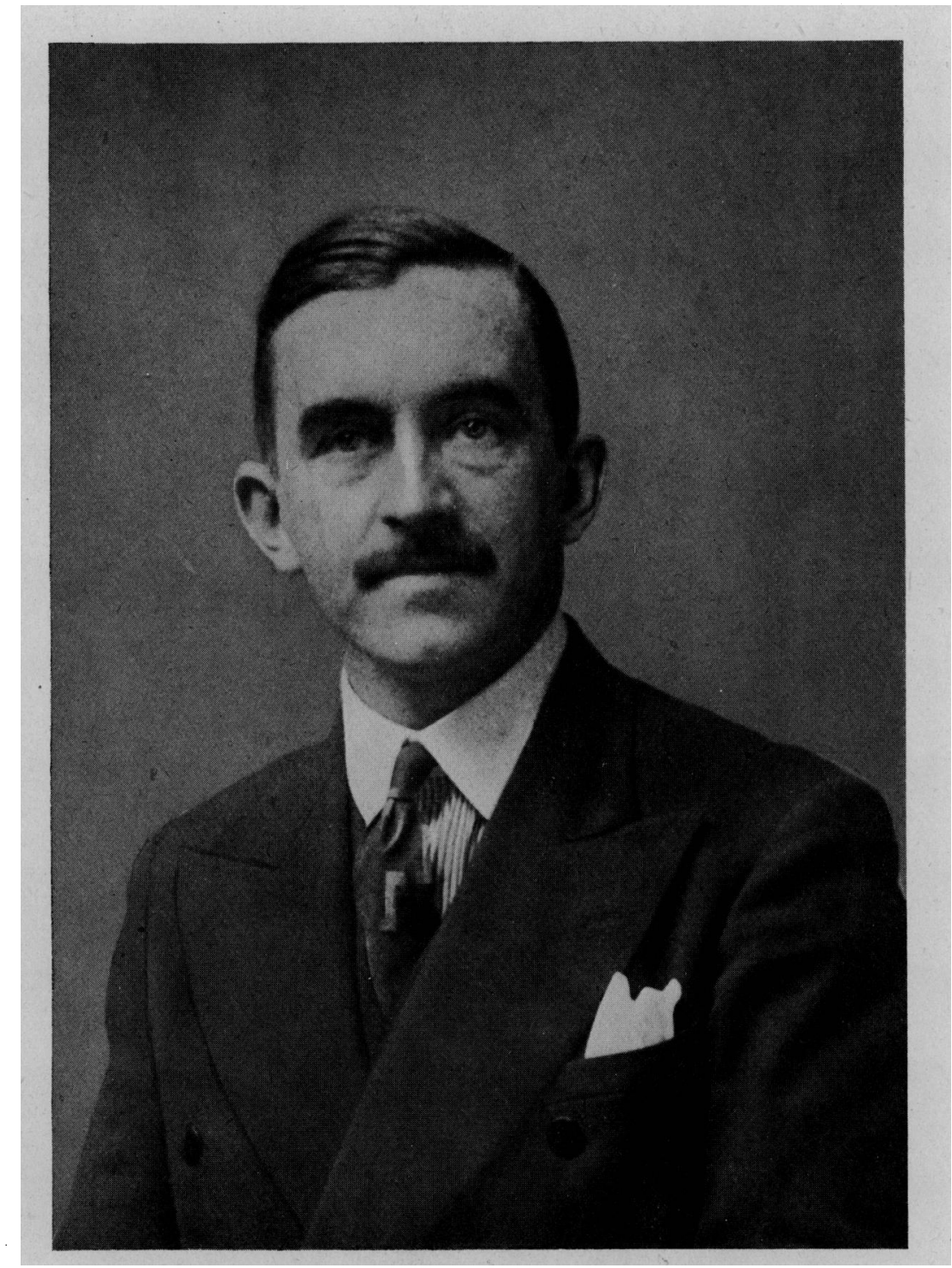

IAN STEWART MCGREGOR 
as Senior Assistant to the University Department of Ophthalmology. Despite the great demands of hospital practice in the war years he became a Fellow of the Royal Faculty of Physicians and Surgeons and of the Royal College of Surgeons in Edinburgh. He graduated M.D. in 1943, the subject of his thesis being the "eftect upon the eyes of methyl alcohol poisoning." Self critical he published only after his precise staking of the known boundaries of ophthalmology. His publications included the following important papers :-

Orbital cellulitis from gas producing organisms. Brit. Med. $J l ., 1,292-293,1942$.

Reticulin content and prognosis in malignant melanoma of uvea. Arch. Ophthal., 30, 291-297, 1943 (with Hill, J.).

Study of histopathological changes in retina and late changes in visual field in acute methyl alcohol poisoning. Brit. Jl. Ophthal., 27, 523-543, 1943.

Quinine blindness. Lancet, 2, 566-567, 1944 (with A. Loewenstein).

Bilateral partial ectasia of nerve head with peripapillary ectasia. Brit. Jl. Ophthal., 28, 618-622, 1944.

Macular coloboma with bilateral grouped pigmentation of retina. Brit. Jl. Ophthal., 29, 132-136, 1945.

Segmental movement of pupil. Brit. Med. Jl., 1, 629-630, 1945.

Cyclic oculomotor palsy. Jl. Neurol. Neurosurg. and Psychiat., $8,22-23,1945$.

His scientific enthusiasm was tempered by the wider necessities. $\mathrm{He}$ was a dependable colleague, and his knowledge of the known limits and an imagination for the stretch beyond made his opinion on a case or problem sound and stimulating. This was often freshened by his piquancy of phrase. His patients were particularly fond of him, his keen mind and natural compassion rarely leading him astray in that proper blending of assessment and charity which they require. Deeply interested in literature and in the countryside he was a good example of what these, combined with an experience of general practice can do to perfect the interests and quality of a speciality. $\mathrm{He}$ was unmarried, and our very sincere sympathies go to his mother on her great loss.

\section{NOTES}

Honour

Mr. Colville Muirhead has been elected an Hon. Member of the Societé belge d'ophtalmologie. 